\title{
A Genealogy of Lust
}

The Use of Hesiod's Theogony in the LXX Translation of the Book of Proverbs

\author{
Vladimir Olivero \\ University of Oxford, Oxford, UK \\ vladimir.olivero@wolfson.ox.ac.uk
}

\begin{abstract}
In this study I argue that the translator of Prov 24:50-51 LXX (30:15-16 MT) adapts the Hebrew text to his Hellenistic audience by alluding to Hesiod's Theogony. The core message of these verses - the ineluctability of cosmic greed-remains the same, yet the images employed in the Septuagint are engrained in and originally belong to the Hellenic mythological understanding of how the universe came into being. The use of classical literature to convey the message contained in the texts of the Hebrew Bible speaks to the hybrid character of the Jewish community of the Egyptian diaspora. When the translator quotes or alludes to Greek literature, he is not borrowing foreign material, but rather drawing wisdom from his very own well. In Alexandria, the waters that flowed from the rock at Horeb and from the Hippocrene spring have merged their course.
\end{abstract}

\section{Keywords}

Septuagint - book of Proverbs - Hesiod - Theogony - Second Temple Judaism

\section{Two Sides of the Same Coin: The Hybrid Nature of the Septuagint ${ }^{1}$}

The Septuagint is a symbolic work. The word "symbol" derives from the Greek

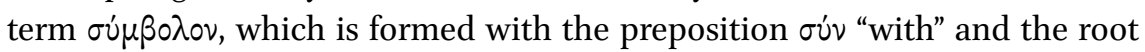

1 I would like to thank John Screnock for inviting me to publish this article as part of the set of papers from the Horizons in Textual Criticism conference. His feedback and help during the writing and editing processes have been invaluable. I would also like to thank Alex Kirk for pointing me to secondary literature that could provide a better framework for my argument. 
$\beta \alpha \lambda$ - "to throw." It conveys the idea of "throwing together," or, even better, "piecing together." This latter translation suits very well both the literal and the non-literal meaning of $\sigma \dot{u} \mu \beta 0 \lambda$ ov. The LSJ gives the following definition of term: "tally, i.e. each of two halves or corresponding pieces of an $\dot{\alpha} \sigma \tau p \dot{\alpha} \gamma \alpha \lambda$ os or other object, which two $\xi \dot{\varepsilon} v o l$, or any two contracting parties, broke between them, each party keeping one piece, in order to have proof of the identity of the presenter of the other."2 A $\sigma \dot{v} \mu \beta \circ \lambda \circ v$ is the half of something that finds and fulfils its meaning only by virtue of being pieced together with its other half. The most illustrious occurrence of the word $\sigma \dot{u} \mu \beta 0 \lambda$ ov appears in the description of humankind drawn by Socrates in Plato's Symposium (191D):

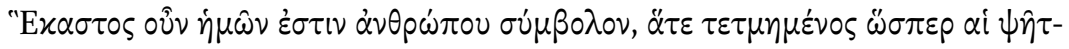

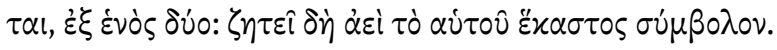

Each of us, then, is but a tally of a man, since everyone shows like a flatfish the traces of having been sliced in two; and each is ever searching for the tally that will fit him. ${ }^{3}$

The Septuagint, which constitutes the intellectual effort and the product of the encounter of Jewish and Greek Hellenistic cultures, embodies the notion of $\sigma \dot{u} \mu \beta 0 \lambda$. An excellent example of its symbolic character is the book of Proverbs. The Greek version is a flexible, literary translation and is acknowledged as one of the freest and most creative pieces among the translated books of the Greek Bible. ${ }^{4}$ Proverbs is a literary gem of Hellenistic Judaism, which stems from a milieu where Jewish and Greek elements have melted and given birth to a unique, hybrid culture. ${ }^{5}$

2 LSJ $\sigma \dot{\mu} \mu \beta \circ \lambda \circ v$.

3 Plato, Lysis, Symposium, Gorgias, ed. and trans. Walter R.M. Lamb, LCL 166 (Cambridge, MA: Harvard University Press, 1925), 140-141.

4 Johan Cook, The Septuagint of Proverbs:Jewish and/or Hellenistic Proverbs?, VTSup 69 (Leiden: Brill, 1997), 316-321. James Aitken, "Poet and Critic: Royal Ideology and the Greek Translator of Proverbs," in Jewish Perspectives on Hellenistic Rulers, ed. Tessa Rajak, Sarah Pearce, James Aitken, and Jennifer Dines, HCs (Berkeley: University of California Press, 2007), 194196; Michael V. Fox, Proverbs: An Eclectic Edition with Introduction and Textual Commentary, нвс E (Atlanta: sbl Press, 2015), 40; Al Wolters, Proverbs: A Commentary based on Paroimiai in Codex Vaticanus, scs (Leiden: Brill, 2020), 1.

5 On the idea that Hellenistic Judaism constituted a Hellenistic culture that could claim as its own some distinctively Greek features see Justin P.J. Schedtler, "Perplexing Pseudoepigraphy," JAJ 8 (2017): 69-89. According to Schedtler, at least some Jews would see Greek literature as their own and use it accordingly to convey their message. See also Erich S. Gruen, Heritage and Hellenism: The Reinvention of Jewish Tradition, HCs (Berkeley: University of Cali- 
In what follows, I will illustrate the hybridity of the Septuagint with an example from the translation of Proverbs (LXX 24:50-51). In this passage, the translator reshapes the text by adding elements drawn from Hesiod's Theogony. Though they are expressed using slightly different images, the message of both the Hebrew and the Greek remain one and the same, with the latter building on the former by grafting references to Classical literature into the source text. ${ }^{6}$

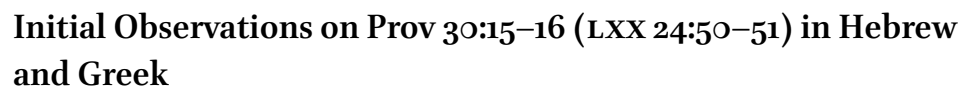

The Hebrew text of Prov $30: 15^{-16}$ is as follows:

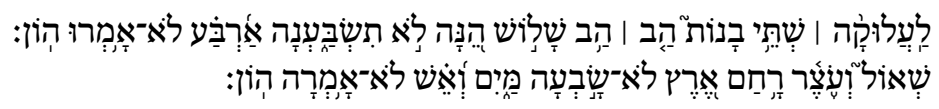

The leech has two daughters: "Give! Give!" Three things there are that are insatiable, four that do not say "Enough!":

She'ol, and barrenness, the earth which is not sated with water, and fire, which does not say "Enough!"7

Verse 16 lists four entities that stand out for their insatiability. ${ }^{8}$ The enumeration of the elements occurring in this verse caps off a series of admonitions against greed and against the lack of respect towards one's parents and, ultimately, God. A prideful attitude is the wages of avidity and the outcome of a life spent hoarding limitless amounts of goods. This theme is first introduced in Agur's prayer, where he asks God to safeguard him from both poverty and wealth (vv. 8-9).

In v. 15, greedy rapaciousness is embodied by the leech. The nature of her two daughters is elliptically summed up in their names:הב הב. Arguably, the term may also refer to the two heads or mouths of the leech, conveying the same

fornia Press, 1998), xiv; Aitken, "Poet and Critic", 202-203; Anathea Portier-Young, Apocalypse against Empire: Theologies of Resistance in Early Judaism (Grand Rapids, MI: Eerdmans, 2011), 107-108; Marieke Dhont, Style and Context of Old Greek Job, JSJSup 183 (Leiden: Brill, 2017), 66-93.

6 Many more references and allusions to Greek literature occur in Proverbs. David-Marc D' Hamonville, Les Proverbes, (Paris: Les Éditions du Cerf, 2000) is a great resource for this.

7 Unless noted otherwise, translations of the Hebrew Bible are my own.

8 The ensuing brief overview of the passage relies on the insightful commentary found in Michael Fox, Proverbs 10-31, AB 18B (New Haven: Yale University Press, 2009), 867-869. 
image of excessive greed. Through a graded numerical sequence, the author of the proverb introduces the four new elements of v. 16. These are even greedier than the leech: She'ol, a barren womb, the earth which is not sated with water, and fire. These are all phenomena of the natural world, and their identity is defined by their unappeasability. ${ }^{9}$ Cosmic insatiability permeates the world in which we live. Everything around us shouts "give, give!" There is no way to alter this reality; we can only meditate on the indifferent cruelty with which nature exacts a toll from humanity when they least expect it. ${ }^{10}$

Moving to the Greek translation, the Greek version of Proverbs can be rather different from its Hebrew Vorlage, and the translator often adapts his text to the target audience.

Proverbs 24:50-51 ${ }^{11}$

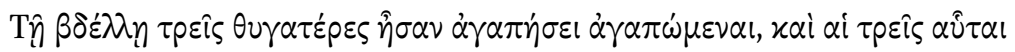

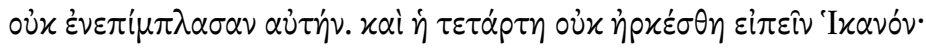

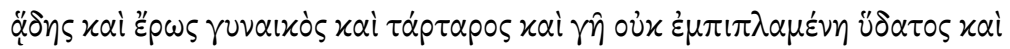

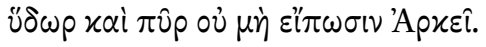

The leech has three lovingly beloved daughters, ${ }^{12}$ but these three did not satisfy her, and the fourth was not pleased to say "Enough!":

Hades and love of a woman and Tartarus and earth not filled with water, water and fire also will never say "It suffices!"

NETS

A few changes in content and some additions are salient in v. 51, as the table below shows: $:^{13}$

9 See also Roland E. Murphy, Proverbs, wвс (Grand Rapids, MI: Zondervan, 1998), 234-235.

10 This notion of cosmic insatiability can be found in many cultures throughout history; so, too, thinking of worldly elements in categories like earth, water, fire, death, and love/Eros (see below, on the Greek text) is not uncommon. See, for example, the following lines from the Panchatantra: "Fire is not sated with wood, nor the ocean with the streams, nor death with all the living, nor the beautiful-eyed with men"; Franz Delitzsch, Biblical Commetary on the Proverbs of Solomon, trans. M.G. Easton (Edinburgh: T\&T Clark, 1882), 2:29o.

11 In some translations such as NETS and La Bible d'Alexandrie these verses are numbered according to the Hebrew, i.e. 30:15-16.

12 On the reading $\alpha \gamma \alpha \pi \dot{\gamma} \sigma \varepsilon \mathrm{\alpha} \dot{\gamma} \alpha \pi \dot{\omega} \mu \varepsilon v \alpha \mathrm{l}$, see Fox, Proverbs, 383-384; on how to render the phrase, see Wolters, Proverbs, 237.

13 On the translator's rendering of мт 30:15 in v. 5o, see Fox, Proverbs, $383^{-}-384$. 


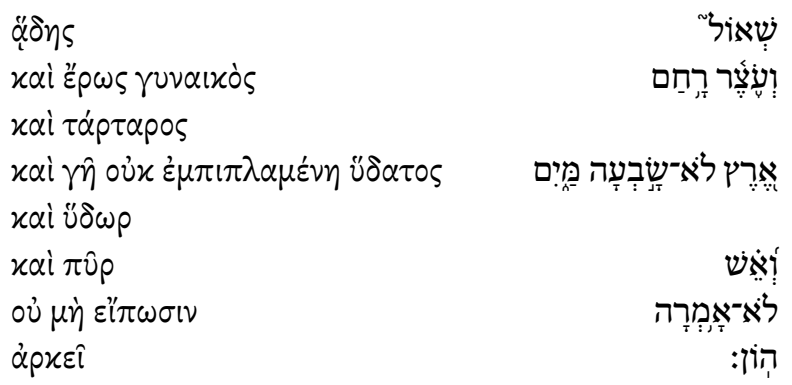

The Hebrew term שאול occurs nine times in Proverbs and is nearly always translated into Greek as $\alpha 0 \delta \varsigma^{14}{ }^{14}$ The sole exception is found in 23:14, where the semantically overlapping noun $\theta \dot{\alpha} v \alpha \tau o \varsigma$ is employed. The expression עצר רחם (literally, "restraint of the womb") is changed into the opposite image of

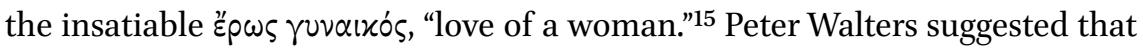

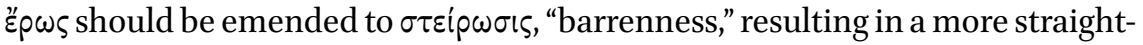
forward translation. ${ }^{16}$ Fox explains हैpws as stemming from רחם via the Aramaic verb of the same root, meaning "love."17 Jan de Waard indicates that the translator arrived at हैpws by metathesis (ערץ to עצר ) ערץ) and transcription

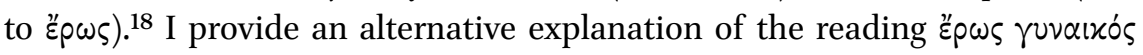
below. ${ }^{19}$ Though the change removes the idea of barrenness from the text, हैpw ruvaixós conjures up no less tragic and grim scenarios, as we shall see shortly.

14 Prov 1:12; 5:5; 7:27; 9:18; 15:11, 24; 27:20; 30:16. For the equivalence of שאול with $\ddot{\alpha} \delta \eta \varsigma$ cf. Sidney Jellicoe, "Hebrew-Greek Equivalents for the Nether World, its Milieu and Inhabitants, in the Old Testament," Textus 3 (1973): 1-2.

15 Cf. Judg. 5:30, where רחם stands for 'woman'.

16 He cites Philo Spec. 3.62 ( $\sigma \tau \varepsilon i p \omega \sigma \iota \varsigma$ for the concept of barrenness in Num 5:23-28); Isa

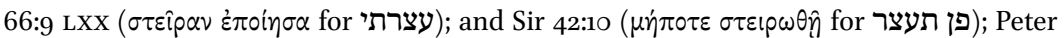
Walters, The Text of the Septuagint: Its Corruptions and Their Emendation, ed. D.W. Gooding (Cambridge: Cambridge University Press, 1973), 290; and see Peter Katz, "Eyes to the Blind, Feet to the Lame," in 'And Other Pastors of thy Flock': a German Tribute to the Bishop of Chichester, ed. F. Hildebrandt (Cambridge: Cambridge University Press, 1942); Peter Walters, review of Biblia Hebraica; 13. Heft 1938, TLZ 63, 1938, col. 34.

17 Fox, Proverbs, 384.

$18 B H Q$ Proverbs, 55. On the possibility that the translator intentionally made these two moves, see Jan de Waard, "Metathesis as a Translation Technique?" in Traducere navem: Festschrift für Katharina Reiß zum 7o. Geburtstag, ed. Justa Holz-Mänttäri and Christiane Nord, Studia translatologica 3 (Tampere, Finland: University of Tampere, 1993), 249-26o.

19 It should be noted that my explanation does not necessarily preclude Fox's and/or de Waard's, inasmuch as the translator could have combined exegetical techniques (Fox's diagnostic Aramaism and de Waard's metathesis plus transcription can be seen as intentional moves made by the translator) with the compositional techniques I describe below. 


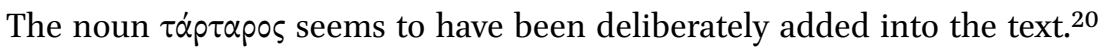
The translator may have taken ארץ with, i.e., "womb of (the) earth," to create this new reading, so that both Hebrew terms are somehow represented in the LXX. Táp $\tau \alpha$ pos is also found in Job 40:15 and 41:23. As in Proverbs, the Joban occurrences are original to the Greek translation and do not appear to have a

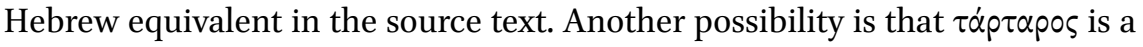
doublet and corresponds to שאול of the Hebrew text. ${ }^{21}$

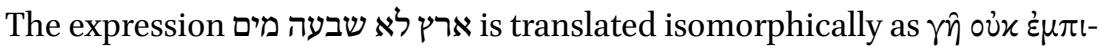
$\pi \lambda \alpha \mu \varepsilon \dot{v} \eta \ddot{u} \delta \alpha \tau \circ \varsigma$. According to most commentators, the term $\ddot{\delta} \delta \omega \rho$ is mistakenly redoubled in the Greek, ${ }^{22}$ though I suggest another possibility for the doublet

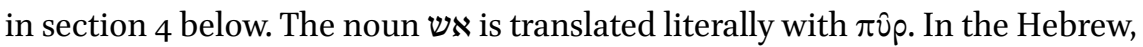
the verb אמר agrees in gender and number with the last member of the list, אש, whereas in Greek the translator uses the verb in the plural and thus refers it to all the preceding grammatical subjects. Finally, while the Hebrew has the noun at the end of both 30:15 and 16, the Greek translates the latter noun with the verb $\dot{\alpha} \rho x \varepsilon \dot{\varepsilon} \omega$ in 24:51; $\dot{\alpha} \rho x \varepsilon \dot{\varepsilon} \omega$ is already employed in v. 50 and is almost identical to ixavóv, the noun used for הון at the end of v. $5^{\circ}$.

To sum up, the most significant discrepancies between the Hebrew and the Greek texts consist in the change from עצר רחם into ěpws ruvalxós, the addi-

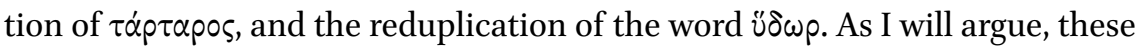
changes are meaningful and unveil the cultural background to which the translator skilfully endeavours to adapt his work.

\section{Hesiod's Theogony and the Origin of the Cosmos}

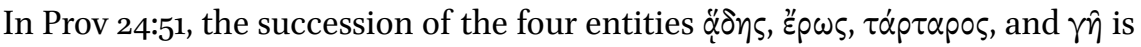
conspicuous. The Hebrew text describes the reality of cosmic insatiability. The Greek translator, a careful listener and student of the Hebrew text, reshapes it by changing the referents in order to convey the same meaning through an

20 Goff notes that Tartarus appears only here in Lxx Proverbs, see Matthew Goff, "Subterranean Giants and Septuagint Proverbs: The 'Earth-Born' of Lxx Proverbs," in With Wisdom as a Robe: Qumran and Other Jewish Studies in Honour of Ida Fröhlich, ed. Károly D. Dobos and Miklós Köszeghy (Sheffield: Sheffield Phoenix Press, 2009), 151.

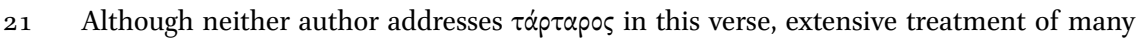
doublets in Proverbs can be found in Paul de Lagarde, Anmerkungen zur griechischen Übersetzung der Proverbien (Leipzig: F.A. Brockhaus, 1863) and in Antoine J. Baumgartner, Étude critique sur l'état de texte du livre des Proverbes d'après les principales traductions anciennes (Leipzig: W. Drugulin, 189o). 
image familiar to his Greek-speaking audience. For the Greek mind, existence is not just a matter of ontology and chronology, but first and foremost of genealogy. Not only the mere past is to be investigated, but the very source and origin of everything. Therefore, cosmic insatiability must be explained and understood as an inherent quality of the universe since its very beginning.

For the Greeks, the most prominent description of the genealogy of their cosmos possibly belonged to Hesiod. ${ }^{23}$ In his Theogony, after the long hymn to the Muses, the poet begins to recite the origins of the universe (vv. 116-122):

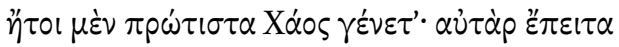

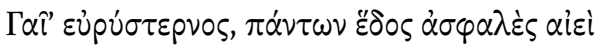

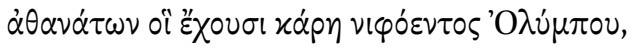

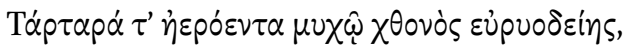

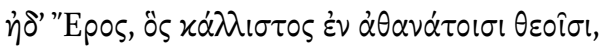

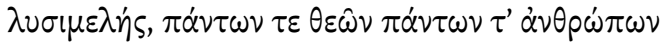

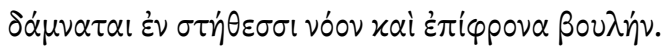

In truth, first of all Chasm came to be, and then broad-breasted Earth, the ever immovable seat of all the immortals who possess snowy Olympus' peak and murky Tartarus in the depths of the broad-pathed earth, and Eros, who is the most beautiful among the immortal gods, the limbmelter-he overpowers the mind and the thoughtful counsel of all the gods and of all human beings in their breasts. ${ }^{24}$

First, avidum Chaos, as Theseus calls it in Seneca's Hercules furens (v. 677), ${ }^{25}$ came into being. Then the earth and Tartarus. After the topological principles, Eros appears, the logical principle, the force that enables generation, the incessant thrust to reproduction, what Schopenauer would centuries later call Wille

23 Hesiod was still a widely read, quoted, studied, and edited author in Hellenistic Alexandria, so it is expected that both the translator and the audience would be acquainted with his foundational works, cf. Stephen Scully, Hesiod's Theogony: from Near Eastern Creation Myths to Paradise Lost (Oxford: Oxford University Press, 2015), 122-159. Furthermore, some of the fragments of the so-called "Pseudonymous Greek Poets" referred to in n. 4 are attributed to Hesiod.

24 Hesiod, Theogony, Works and Days, Testimonia, ed. and trans. Glenn V. Most, LCL 57 (Cambridge, MA: Harvard University Press, 2018), 12-13.

25 Seneca, Tragedies, Volume I: Hercules. Trojan Women. Phoenician Women. Medea. Phaedra, ed. and trans. John G. Fitch, LCL 62 (Cambridge, MA: Harvard University Press, 2018), 70. 
zum Leben. There is no teleological principle governing the ongoing generation and reproduction of nature, only the causal drive of Eros in and by itself. ${ }^{26}$ This primordial force is embodied later in the Theogony (v. 201) by the god who accompanies Aphrodite along with "I $\mu \varepsilon p \circ \varsigma$ (desire). ${ }^{27}$

What we find in LXX Prov 24:51 is a very explicit allusion to Hesiod's Theogony, used by the author of the Greek version to describe the primordial

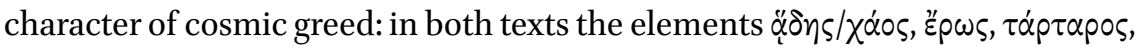
and $\gamma \hat{\eta}$ occur one after the other.

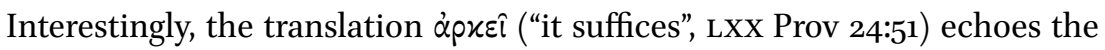
word $\alpha p x \eta \dot{~(p r i n c i p l e, ~ b e g i n n i n g) . ~ I n ~ v . ~} 115$ of the Theogony, just before the account of the beginning, Hesiod asks the Muses to start their narration है $\xi$

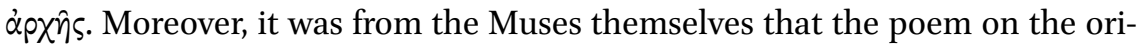

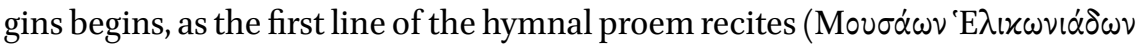
$\dot{\alpha} p \chi \dot{\omega}^{\prime} \mu \varepsilon \theta^{\prime} \dot{\alpha} \varepsilon i \delta \varepsilon(v) .{ }^{28}$ The very same entities that set the cosmic machine into motion are borrowed by the translator of Proverbs to convey the idea of original and foundational unappeasability. Insatiability is ingrained in the fibres that constitute our world.

One might object that in Proverbs we find $\alpha \dot{\delta} \eta \varsigma$ rather than $\chi \dot{\alpha} \circ$ s; this is not problematic, however. First, as we have already seen, this is the usual term employed to translate שאול. Second, $\chi \alpha$ dos is the gaping mouth, as PseudoOppian puts it in his Cynegetica (III, 414) ${ }^{29}$ - the huge chasm $\left(\chi \alpha \dot{\sigma} \sigma \alpha \mu \varepsilon^{\varepsilon} \gamma \alpha\right.$, Theogony v. 740 $)^{30}$ that lies between the surface of the earth $(\chi \theta \dot{\omega} \nu)$ and Tartarus (cf. Theogony vv. 736-745 and 807-814). ${ }^{31}$ Because of its geographical location and qualitative description, $\chi \dot{\alpha} 0 \varsigma$ and $\alpha \dot{\delta} \eta \varsigma$ can easily be identified with one another. Moreover, Pseudo-Apollodorus notes that Tartarus, dark as Erebos, is a region in Hades (Bibliotheca 1.1). ${ }^{32}$ X'́os's voraciousness is intrinsic in its very name: the term is related to verbs such as $\chi \dot{\alpha} \sigma x \omega \omega$ (to yawn, open the mouth) and $\chi \alpha v \delta \dot{\alpha} v \omega$ (to contain) and is properly translated as chasm. Even the Latin poets give us a vivid description of its rapaciousness. Lucan, in his Pharsalia

26 Mitchell Miller, “First of all': On the Semantics and Ethics of Hesiod's Cosmology," Ancient Philosophy 21 (2001), 251-276.

27 Hesiod, Theogony, 18.

28 Hesiod, Theogony, 2.

29 Oppian, Colluthus, Tryphiodorus, Oppian, Colluthus, and Tryphiodorus, trans. Alexander W. Mair, LCL 219 (Cambridge, MA: Harvard University Press, 1928), 148.

3o Hesiod, Theogony, 62 .

31 Hesiod, Theogony, 62, 66.

32 Apollodorus, The Library, Volume I: Books 1-3.9, trans. James G. Frazer, LCL 121 (Cambridge, MA: Harvard University Press, 1921), 4. 
(6.969) speaks about Chaos innumeros avidum confundere mundos, ${ }^{33}$ whereas Valerius Flaccus, in the Argonautica (I, 830), affirms that ingenti iacet ore Chaos, quod pondere fessam materiem lapsumque queat consumere mundum. ${ }^{34}$ The very same idea is repeated in Proverbs 27:20, both in the Hebrew and in the Greek:

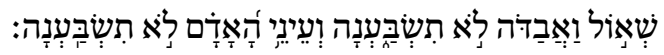

She'ol and Abaddon are not satisfied, and the eyes of the man are not satisfied

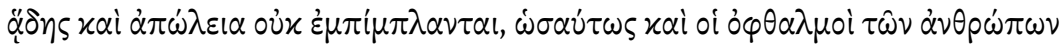
$\ddot{\alpha} \pi \lambda \eta \sigma \tau 0 l$.

Hades and destruction are never satisfied; likewise insatiable are the eyes of the people

NETS

As for Eros, it is remarkable that the occurrence in LXx Proverbs has a very different meaning from that in Hesiod. It is not the logical principle, nor the vital force that permeates the cosmos. It is employed as a byword for lust and greed, in 24:51 and elsewhere. ${ }^{35}$ Eros as an act of lust is already announced in v. $5^{\circ}$. The Hebrew imperatives הב הב are translated as $\dot{\alpha} \gamma \alpha \pi \dot{\eta} \sigma \varepsilon l \dot{\alpha} \gamma \alpha \pi \dot{\omega} \mu \varepsilon v \alpha$, with an emphatic and almost redundant repetition of the great love that mother leech has for her three daughters. ${ }^{36}$ That this is not a healthy kind of love is made clear in the following stich, where it is stated that the daughters do not fill her. The "fourth one" ( $\dot{\eta} \tau \varepsilon \tau \dot{\alpha} p \tau \eta)$ might be the mother again, who cannot say: "Enough!". This scene could have led the translator to adopt the image of the Ěpws ruvauxós in the following verse. The leech would thus be an instance of the woman as personification of Folly, of which greed and lust are outcomes. That Eros refers to lust and greed here stems naturally from its meaning "desire." In the Symposium, for example, Plato's Eros differs significantly from Hesiod's. In the Symposium, Socrates examines Agathon's speech and draws a connection

33 Lucan, The Civil War (Pharsalia), trans. James D. Duff, LCL 220 (Cambridge, MA: Harvard University Press, 1928), 354.

34 Valerius Flaccus, Argonautica, trans. John H. Mozley, LCL 286 (Cambridge: Harvard University Press, 1934), 66.

35 So Fox, Proverbs, 384.

36 The translator played here with the similar root אהב 'to love'. 
between Eros, desire ( $\dot{\varepsilon} \pi(\theta u \mu i \alpha)$, and need: when a person loves, there is something they want and, therefore, something or someone they need and lack. It is always Eros of something $(199 \mathrm{E})$ :

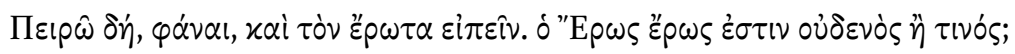

Now try and tell me about Love: is he a love of nothing or of something?37

Eros is the son of Penia: when we love we are in a state of poverty, and we stop loving when we possess what we were trying to grasp.

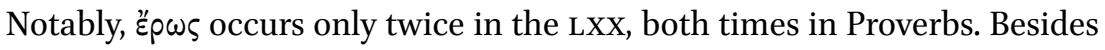
our present case, it occurs in 7:18, where the adulterous woman-who represents the antagonist of Lady Wisdom, personified as another woman in ch. 8invites the young man to "wrap up in love" ( $\dot{\xi} \gamma \chi \nu \lambda เ \sigma \theta \omega \hat{\omega} \mu \nu$ है $\rho \omega \tau \iota)$. There could be an intratextual reference: the greedy love and lust the author refers to in our passage are exactly those represented in ch. 7. Furthermore, the end of ch. 7 states that the ways of Hades are the house of the seductress $(7: 27) ; 38$ Hades and Eros similarly occur side by side in 24:51.

An element that deserves further attention is the term $\tau \dot{\alpha} \rho \tau \alpha \rho \circ$, which seems to have no counterpart in the Hebrew text.

According to Hesiod, Tartarus is situated under the ground and lies as far from the surface of the earth as the sky rests above it (vv. $720-725) \cdot{ }^{39}$ It is into Tartarus that the Hecatoncheires Cottus, Briareus, and Gyges cast the abominable Titans in chains. The hundred-headed Typhon himself, the most frightening among the gods' adversaries, is imprisoned in Tartarus, which had sired him after mingling with Gaia. In the Iliad, Zeus threatens the other gods, affirming that he could lock them up in Tartarus if he wished so, because he is the most powerful (VIII, 13). ${ }^{40}$ After defeating the Titans, the Olympian gods had to face a new challenge, the Giants, born from the blood of the emasculated Uranus which was spilled on Gaia. This prodigious breed of monsters, once

37 Plato, Symposium, $166-167$.

38 See also D' Hamonville, Proverbes, 303 .

39 Hesiod, Theogony, 6o.

40 Homer, Iliad, Volume I: Books 1-12, trans. Augustus T. Murray, rev. William F. Wyatt, LCL 170 (Cambridge, MA: Harvard University Press, 1924), 350. 
vanquished and tamed, was buried under the volcanoes of Greece and Italy. By reason of the many overlapping motives that characterize this mythologem, Titans and Giants were confused and conflated as early as the sixth century BCE, as the testimony of Xenophanes seems to indicate (frag. 1 ).$^{41}$ Burnett finds three distinctive traits that would define Tartarus throughout Greek history: location within Hades, function as a prison and place of punishment, stygian environment. ${ }^{42}$ The idea of retribution and punishment in Tartarus is already attested in Pindar (Olympica 2.50-61) and later spread by Orphism. ${ }^{43}$

The appropriation of Greek mythology in Second Temple Judaism is worth mentioning for our purposes. ${ }^{44}$ By stating that שאול is equivalent to Greek ¿ूo $\delta \varsigma$, Judaism imported the elements of Greek mythology into its thought-

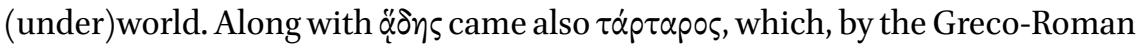

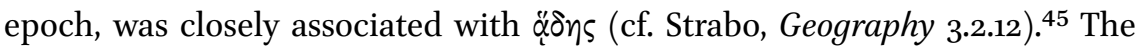
inhabitants of these murky places were also imported into Judaism. To mention the most notable examples, the fragments reported by Alexander Polyhistor, 1Enoch, the Third Sybil, and Jubilees offer lengthy treatments of the biblical story of Gen 6. The account about the angels and giants is couched in the familiar language of Greek mythology. Much of the Greek mythology is adopted and reworked in these texts. ${ }^{46}$ The idea that the prediluvian angels who rebelled and corrupted the earth are chained in underworldly prisons surrounded by fire is a widespread motif of the literary production of Hellenistic Judaism. In the Sibylline Oracles, the Titans and the Giants are grouped together with those who perished in the deluge. By the same token, in the Septuagint we find the

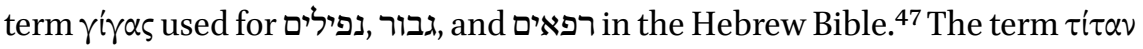
translates רפאים in 2 Sam 5:18 and 22.

41 Tyrtaeus, Solon, Theognis, Mimnermus. Greek Elegiac Poetry: From the Seventh to the Fifth Centuries BC, ed. and trans. Douglas E. Gerber, LCL 258 (Cambridge: Harvard University Press, 1999), 414.

42 Clint Burnett, "Going Through Hell; taptapos in Greco-Roman Culture, Second Temple Judaism, and Philo of Alexandria," JAJ 4 (2013): 352-378.

43 Pindar, Olympian Odes. Pythian Odes, ed. and trans. William H. Race, LCL 56 (Cambridge, MA: Harvard University Press, 1997), 68.

44 For a detailed outline functional to the present discussion see Loren T. Stuckenbruck, "The 'Angels' and 'Giants' of Genesis 6:1-4 in Second and Third Century вС E Jewish Interpretation: Reflections on the Posture of Early Apocalyptic Traditions," DSD 7 (2000): 354-377.

45 Strabo, Geography, Volume II: Books 3-5, trans. Horace L. Jones, LCL 5 O (Cambridge, MA: Harvard University Press, 1923), 5 o.

46 See Goff, "Subterranean Giants," 146-156, for a nice example on the Greek traditions regarding giants, titans, and the netherworld.

For נפילים see Gen 6:4; Num 13:3; Ezek 32:27; for גבור see Gen 6:4; 10:8-9; Isa 13:3; 49:24-25; 
We find hints of the same eclectic account in three places where the Septuagint deliberately introduces the infamous Tartarus. Besides our text in Prov 24:51, Tartarus appears in Job 40:2O and 41:24a.

Job 40:20

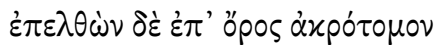

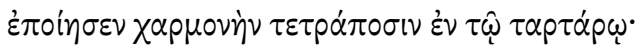

But when it went up on a steep mountain, it brought gladness to the quadrupeds in Tartarus.

NETS

Job 41:23-24a

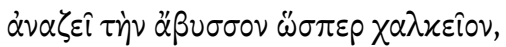

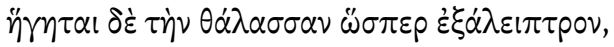

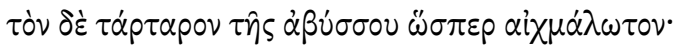

It makes the deep boil like a caldron and regards the sea as a pot of ointment and Tartarus of the deep as a captive.

NETS

As for the Joban verses, I believe that the translator was somehow inspired by the monstrosity of the creatures described to draw from the eclectic mythology characteristic of Second Temple Judaism. Behemot and Leviathan probably reminded him of the long list of infernal animals that inhabit Hades. The elements are all contained in the Hebrew text. For instance, Behemot's tail is described in 40:12, and his bronze-like bones in 40:13. The reader easily recalls the detailed description of the bronze-voiced Cerberus and its tail in Hesiod's Theogony. At this point, the translator embellishes his work with some more frightening images that may conjure up the vivid picture of a ghastly underworld in which this terrifying creature moves. Therefore, in vv. 14 and 15 he introduces the myth of the fallen angels and Tartarus itself. The overlapping of Greek and Jewish mythology is thus completed. Likewise, the image of Tartarus and captivity in Job 41:23-24a occurs in the description of Leviathan, which has already been translated in 40:25 as $\delta \rho \alpha ́ x \omega \nu$. Chimera,

Ezek 32:12, 21, 27; 38:18, 20; for רפאים see Gen 14:5; Josh 12:12; Isa 14:9; Job 26:5; Prov 21:16; 1Chr 11:15; 14:9; 20:4. 
who had in its hinder part a dragon head, is described by Hesiod in the same list of Echidna's impious offspring where also Cerberus recurs. In summary, the stygian elements of Tartarus and the imprisoned angels allow the translator of Job to offer a more impressive description of the two prodigious creatures.

Like the translation of Job, the Greek text of Proverbs adds many more details on the netherworld. In 23:27, for instance, the Hebrew text describes the prostitute (זונה) as a deep pit (שוחה עמוקה). The Greek translator changes (or misreads, or, perhaps, has a different source) זרה into זונה in (cf. נכרה in the

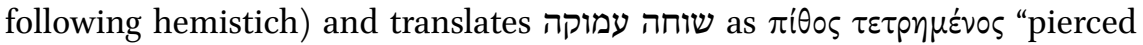
cask,"48 though the same phrase is translated literally in $22: 14$ as $\beta$ ó $\theta$ pos $\beta \alpha \theta$ v́s.

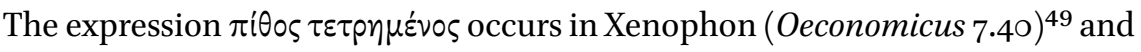
Aristotle (Oeconomica $1344 b)^{50}$ in its everyday meaning of "labour in vain." This labour was the punishment of the Danaids, murderers of their husbands, who had to incessantly fill with water a pierced cask in Hades, as Plato tells us in the Gorgias (493bc). ${ }^{51}$ It is curious that it is the strange house that is described as a pierced cask. The same adjective describes the strange woman in 7:15 (iv $\alpha \varepsilon$

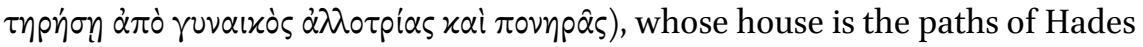
(cf. 7:27). The same image - of the woman as the personification of Folly, whose house is in Hades, and the elements of water and strangeness-occurs at the end of chapter 9 (vv. 13-18). The rovì $\alpha \varphi \rho \omega \nu$, as opposed to Wisdom, sits at the door of her house (v. 14), luring those who walk on their straight paths (v. 15). She offers sweet water of theft (v. 17). The ү $\eta \gamma \varepsilon v \varepsilon i \varsigma$ (earth-born, i.e. Giants and Titans) and Hades are with her. This very same image occurs in 2:17-18, where

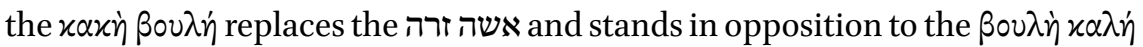

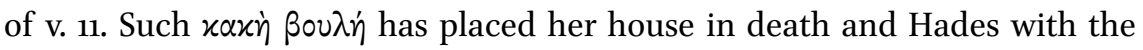

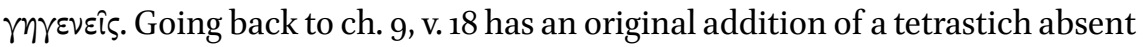
in the Hebrew, in which the image of the dangers of foreign waters, crossing a river, and thirst are described. The injunction not to approach the strange water and not to drink from a strange source recalls the orphic Petelia Gold Tablet from 300-200 BCE, where it is stated that "You will find to the left of the house

\footnotetext{
48 Cf. D'Hamonville, Proverbes, 105-106.

49 Xenophon, Memorabilia. Oeconomicus. Symposium. Apology, trans. Edgar C. Marchant and Otis J. Todd, rev. Jeffrey Henderson, LCL 168 (Cambridge, MA: Harvard University Press, 2013), 454.

50 Aristotle, Metaphysics, Volume II: Books 10-14. Oeconomica. Magna Moralia, trans. Hugh Tredennick and George C. Armstrong, LCL 287 (Cambridge, MA: Harvard University Press, 1935), 338.

$5^{1} \quad$ Plato, Gorgias, 416.
} 
of Hades a spring and standing by it a white cypress. Do not even approach this spring!!"52 Similarly, crossing strange water evokes the Acheron and Styx, and looking at the woman may be an allusion to the myth of Eurydice. ${ }^{53}$

Finally, as we know from the reception history of Gen 6 in the last centuries ВCE, the fallen angels lusted after the daughters of men and sired the giants. These were, at least in part, destroyed by the flood, whose waters covered the entire earth. As for the fallen angels, they are damned to the eternal fire in Tartarus. The double mention of 0 $\delta \omega p$ in Prov 24:51 may be a hint to the episode of the flood, whereas $\pi \hat{v} \rho$, already in the Hebrew, nicely fits the image evoked by the addition of $\tau \dot{\alpha} \rho \tau \alpha$ pos.

In summary, when the translator finds opportunity to add details about Hades and the netherworld, he brings Greek mythological material into the text. He fleshes out the images already present in the Hebrew text and repeats them even when there is no repetition in the source text. The occurrences of Tartarus, love of/for a woman, the earth that cannot be filled with water, and fire in Prov 24:51 are representative elements of the encounter of Greek and Jewish mythologems, which were woven together in the diaspora community and became a distinctive mark of a new hybrid Hellenistic culture.

\section{5}

\section{Conclusion}

Within the Septuagint, the translation of Proverbs is an excellent witness to the hybrid product of the encounter of the Greek and the Jewish Weltanschauungen, not unlike texts such as Ezekiel's' $E \xi \alpha \gamma \omega \gamma$ ' or the fragments of the so-called 'Pseudonymous Greek Poets.' LXX Prov 24:50-51 is a splendid example of the symbolic and syncretistic nature of Alexandrian Judaism and of its literary expressions. In this passage, Hesiod's Theogony is woven into the translation of the Hebrew text in order to convey, with different words and with different images, the same meaning contained in the source text - a reflection on cosmic insatiability and avidity. Besides evoking the greedy and lustful principles that birthed and regulate our reality, the translator's Greek also hints at manifestations and instantiations of these vices through paradigmatic episodes: the love of the woman, which is the love of the woman of ch. 7 , as the unique occurrences of the term है $p \omega \varsigma$ indicate; Hades, Tartarus, Eros, water and fire, which

\footnotetext{
52 Translation taken from F. Graf and S.I. Johnston, Ritual Texts for the Afterlife: Orpheus and the Bacchic Gold Tablets (London: Routledge, 2013), 7.

53 Cf. D'Hamonville, Proverbes, 216-217.
} 
remind the Alexandrian reader of the episode of the fallen angels in Gen 6. The translator-or here we may rightly call him the author-of Lxx Proverbs is working at different levels while creating a text that has a polyhedral meaning and a symbolic nature. 